\section{Barnemishandling mer vanlig enn offisielle tall tyder på}

Barnemishandling er mye vanligere enn offisiell statistikk tyder på. Hvert år blir rundt ett av ti barn mishandlet i høyinntektsland, men offisielle tall tyder på at mindre enn en tidel av disse er undersøkt av barnevernet. Det skriver Ruth Gilbert og kolleger i den første av en serie artikler om barnemishandling i The Lancet (1). Voldelig misbruk rammer $4-16 \%$ av barn i høyinntektsland, og minst $15 \%$ av jentene og $5 \%$ av guttene er blitt utsatt for en form for seksuelt misbruk. Følelsesmessig misbruk, inkludert det å få barn til stadig å føle seg uønsket eller redd, affiserer rundt $10 \%$ barn hvert år.

1-15\% barn blir fysisk og/eller psykisk forsømt hvert år, og omsorgssvikt står for den største andelen av barnevernsrapporter i høyinntektsland $144 \%$ i Storbritannia, $38 \%$ i Canada og $34 \%$ i Australia). - Å bli forsømt som barn er over tid minst like skadelig som fysisk og seksuelt misbruk, men har fått lite oppmerksomhet, sier Gilbert.

For mange barn er mishandling en kronisk tilstand, og mishandling kan ha konsekvenser for resten av livet. - Barnemishandling bidrar vesentlig til mortalitet og morbiditet blant barn, virker negativt inn på psykisk helse og fører til stoffmisbruk (særlig for jenter), fedme og kriminell oppførsel som vedvarer $\mathrm{i}$ voksen alder. De alvorlige og langvarige konsekvensene betyr at mer bør investeres i forebygging og terapeutiske strategier for yngre barn, konkluderer Gilbert.

\section{Oda Riska}

oriska@hotmail.com

Tidsskriftet

\section{Litteratur}

1. Gilbert R, Widom CS, Browne K et al. Burden and consequences of child maltreatment in high-income countries. Lancet 2008. DOI. 10.1016/S0140-6736(08)61706-7.

\section{Obamas helseplan}

\author{
Barack Obamas helseplan er lovende og et positivt steg mot et mer \\ rettferdig helsesystem, heter det i The Lancet. Tre stikkord for \\ «The Obama-Biden plan»- helseforsikring for alle, modernisering \\ av helsesystemet og vekt på forebygging.
}

Problemene i USAs helsesystem er store. 50 millioner amerikanere har ikke helseforsikring, i tillegg har 25 millioner for dårlig forsikring (1). Det er sju millioner flere uten forsikring i dag enn det var i 2000. Forsikringspremiene er nesten doblet, mens inntekten til en gjennomsnittsfamilie har falt med 2000 dollar (2)

Et av hovedpunktene i Obamas plan er å sikre god og rimelig helseforsikring for alle. Ifølge planen skal de årlige helsekostnader gå ned med 2500 dollar for en typisk familie. Det lover altså USAs kommende president (3).

Obamas plan om å tilby flere betalingsmetoder, hans satsing på at alle barn skal ha helseforsikring og kravet om at forsikringsselskapene må dekke eksisterende helseplager er positive steg i retning av et mer inkluderende helsesystem, står det på lederplass i The Lancet (2).

Obama planlegger også å modernisere helsesystemet og redusere de administrative kostnadene. Forskning tyder på at så mye som $30 \%$ av helsekostnadene er uten innvirkning på resultatet for pasienten. Obama håper at det skal bli lavere administrasjonskostnader og mindre ineffektivitet. Sam- tidig vil han tillate mer bruk av generiske medikamenter for å kutte kostnader.

- Planen vil gjøre det mulig for amerikanerne å importere billige legemidler fra utlandet og øke bruken av generiske legemidler, sier Obama. Han vil også legge vekt på forebyggende helsearbeid. Forsikringene må dekke forebyggende tiltak. Mer penger til forebygging vil spare millioner av dollar og gjøre livet bedre for millioner, mener han.

- «The Obama-Biden plan» vil garantere alle amerikanere tilgang til de helsetjenestene de trenger. Foreldre slipper å bekymre seg for at behandlingen av deres syke barn kommer til å ruinere dem, hevder Obama.

\section{Oda Riska}

oriska@hotmail.com

Tidsskriftet

\section{Litteratur}

Schoen C, Collins SR, Kriss JL et al. How many are underinsured? Trends among U.S. adults, 2003 and 2007. Health Aff (Millwood) 2008; 27: w298-309.

2. Obama and health: change can happen. Lancet 2008; 372: 1707

3. Obama B. Affordable health care for all Americans: the Obama-Biden plan. JAMA 2008; 300: 1927-8.

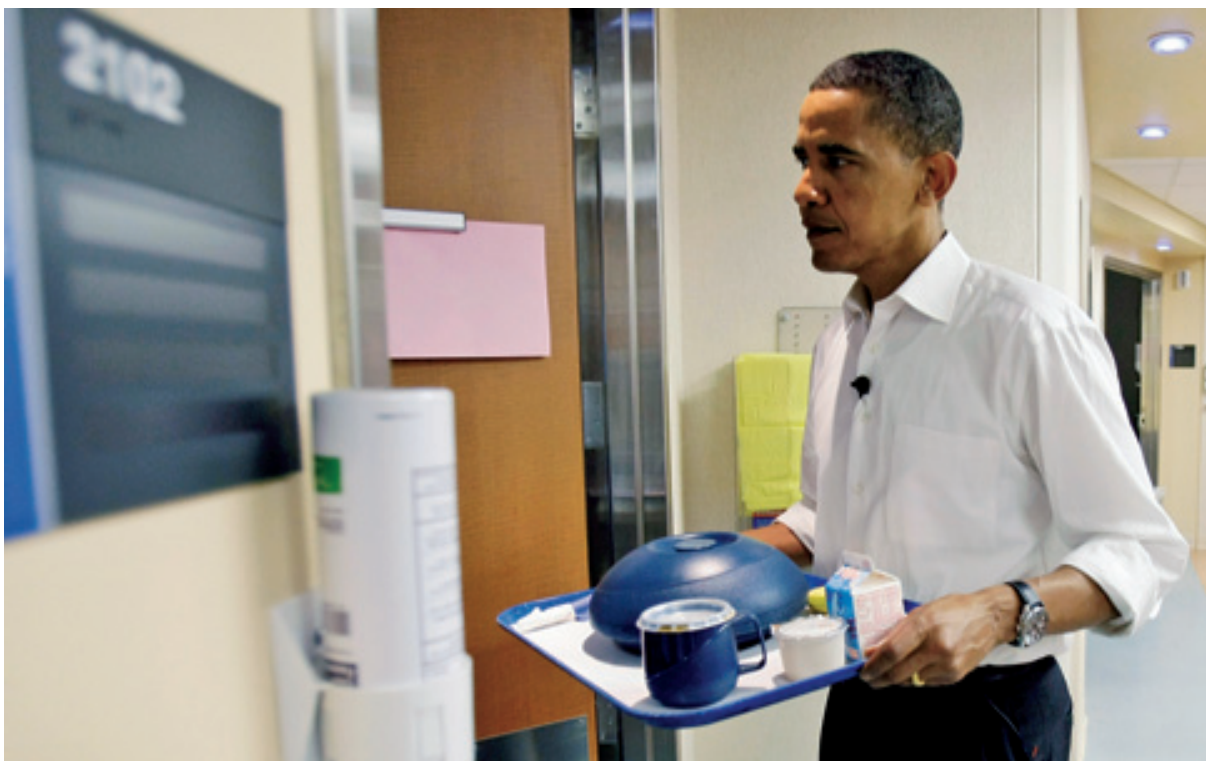

Den kommende presidenten har gjort seg kjent med helsevesenet - her hjelper han til med matserveringen. Foto Alex Brandon/AP Photo/SCANPIX 